\title{
PENERAPAN METODE DISKUSI UNTUK MENINGKATKAN AKTIVITAS SISWA PADA PEMBELAJARAN MENIRUKAN PEMBACAAN PANTUN ANAK DI KELAS IV SD NEGERI 19 KEPAHIANG KABUPATEN KEPAHIANG PROVINSI BENGKULU
}

\author{
Rita Pauziah \\ SDN 19 Kepahiang,Bengkulu
}

\begin{abstract}
Abstrak
Pembelajaran Bahasa Indonesia menggunakan metode diskusi telah dilaksanakan pada SDN 19 Kepahiang tahun ajaran 2013/2014 dengan jumlah 20 orang siswa. Penelitian ini bertujuan untuk meningkatkan aktivitas siswa dalam pembelajaran menirukan pembacaan pantun anak dengan metode diskusi. Penelitian ini dilakukan dengan tiga siklus,yaitu perencanaan, pelaksanaan tindakan, dan refleksi. Teknik pengumpulan data yang digunakan adalah observasi dan tes. Penerapan metode diskusi terbukti dapat meningkatkan prestasi belajar siswa, keberanian,mengemukakan pendapat,serta siswa terlatih beragumentasi.
\end{abstract}

Kata kunci: metode diskusi,aktivitas siswa prestasi belajar

\section{PENDAHULUAN}

Dalam rangka mencerdaskan kehidupan bangsa, sangat diperlukan guru yang professional Untuk menjadi guru yang professional bukanlah hal yang gampang dan dapat dilakukan oleh semua orang. Guru tidak hanya sekedar mengajar dan memberikan materi pelajaran saja akan tetapi seorang guru harus menjadi pembimbing, pelatih model atau teladan pendorong kreativitas dan juga pembaharuan atau inovator bagi siswasiswanya. Oleh karena itu, maka tanggung jawab besar untuk menyiapkan generasi penerus bangsa terletak di tangan seorang guru. Oleh karena itu, seorang guru haruslah berupaya keras untuk melakukan yang terbaik untuk siswanya agar menjadi manusia yang bertaqwa terhadap tuhan Yang Maha Esa cerdas dan memiliki ilmu pengetahuan yang kelak beguna dalam kehidupan bermasyarakat berbangsa dan bernegara.

Kurikulum merupakan pedoman dalam proses pembelajaran,oleh karena itu,setiap kegiatan guru dan siswa dalam proses pembelajaran tidak boleh menyimpang dari kurikulum yang merupakan alat untuk mencapai tujuan nasional.
Bahasa merupakan alat komunikasi yang mengandung beberapa sifat yakni sistematik, manasuka, ujar dan komunikatif (PujiSantosa, 2009).

Metode mengajar merupakan salah satu komponen yang harus ada dalam pembelajaran. Pada dasarnya metode mengajar merupakan cara atau teknik yang digunakan guru dalam melakukan interaksi dengan siswa pada saat proses pembelajaran berlangsung (Winata Putra,2003)

Menurut Puji Santoso (2009) Ada beberapa ciri metode yang baik yaitu: (1) mengundang rasa ingin tahu murid; (2) menantang murid untuk belajar; (3) mengaktifkan mental,fisik,dan psikis murid; (4) memudahkan guru (5) mengembangkan kreativitas murid; dan (6) mengembangkan pemahaman murid terhadap materi yang dipelajari

Berdasarkan hasil observasi yang telah dilakukan oleh teman sejawat terhadap pembelajaran awal yang telah dilakukan guru ternyata rendahnya hasil belajar siswa dan rendahnya keaktifan siswa dalam pembelajaran disebabkan oleh metode yang diterapkan guru 
tidak relevan dengan materi yang diajarkan. Metode pembelajaran yang digunakan adalah ceramah, pada pembelajaran tentang pantun metode tersebut ternyata tidak efektif untuk diterapkan.

Berdasarkan kenyataan di atas, permasalahan tersebut perlu dilakukan perbaikan dan dilakukan penelitian. Atas masalah yang ditemui di kelas IV tersebut guru melakukan Penelitian Tindakan Kelas dengan menerapkan metode diskusi untuk membantu siswa dalam memahami materi pelajaran tentang pantun.

Menurut Mulyasa (1988), metode diskusi dapat diartikan sebagai percakapan responsif yang dijalin oleh pertanyaan-pertanyaan problematis yang diarahkan untuk memperoleh pemecahan masalah.sedangkan berdasarkan Kamus Besar Bahasa Indonesia (1988) diskusi adalah pertemuan ilmiah untuk bertukar pikiran mengenai suatu masalah. Dengan diskusi,guru dan siswa mencoba menyelesaikan suatu permasalahan denganpendapat berdasarkan penalaran. Untuk solusi yang lebih baik siswa ditugaskan untuk berusaha berpikir kreatif dalam memecahkan suatu permasalahan yang ada dalam kehidupan sosial (Winarto, 1990 ).

Berdasarkan kenyataan di atas ,perlu dialakukan metode yang tepat dalam melaksanakan pembelajaran pembacaan pantun anak dengan lafal dan intonasi yang tepat. Untuk meningkatkan aktivitas siswa dalam mengikuti pembelajaran Bahasa Indonesia,kiranya metode diskusi perlu dilakukan.siswa kelas IV SDN 19 Kepahiang kabupaten Kepahiang provinsi Bengkulu berjumlah 20 orang.mereka mayoritas belum aktif dalam mengikuti pembelajaran Bahasa Indonesia. oleh karena itu, untuk perbaikan pembelajaran pada Kompetensi Dasar tersebut perlu dilakukan penelitian tindakan kelas.

\section{METODE}

Penelitian ini dilakukan dengan menggunakan rancangan Penelitian Tindakan Kelas (PTK). Penelitian dilakukan dalam tiga siklus yang terdiri atas empat tahap pokok, yaitu perencanaan, pelaksanaan tindakan, pengamatan, dan refleksi (Kemmis dalam Kasbolah,1999). Penelitian ini diawali dengan melakukan studi pendahuluan. Studi pendahuluan ini dilakukan untuk mengetahui adanya masalah dalam pembelajaran yang telah dilakukan oleh guru di kelas.

Adapun subjek penelitian adalah guru dan siswa-siswi SD Negeri 19 Kepahiang Tahun pelajaran 2013/2014 yang berlokasi di desa Permu kecamatan Kepahiang Kabupaten Kepahiang yang berjarak $3 \mathrm{~km}$ dari pusat kabupaten Kota. Adapun mata pelajaran yang diteliti adalah Bahasa Indonesia dengan kompetensi. Dasar menirukan pembacaan pantun anak dengan lafal dan intonasi yang tepat.

Jumlah siswa yang menjadi subjek penelitian berjumlah 20 orang terdiri dari 9 lakilaki dan 11 perempuan, dengan karakteristik sebagian besaran anak petani yang pendidikan orang tuanya paling tinggi tamat SMA.Waktu penelitian dimulai dari tanggal 15Januari sampai dengan 25 Februari 2013.

Data yang dikumpulkan dalam penelitian ini meliputi skor tes dengan bentuk esai pada akhir setiap siklus, objektif, skor bertanya dan menjawab pertanyaan,dan catatan lapangan yang berkaitan dengan aktivitas siswa dalam proses pembelajaran.

Data yang dikumpulkan berdasarkan teknik observasi dan data disajikan dalam bentuk tabel dengan pengelolaan data dengan rumus :

$$
\text { Ketuntasan }=\frac{\text { jumlah siswa tuntas }}{\text { jumlah siswa }} \times 100
$$

\section{HASIL DAN PEMBAHASAN}

Penelitian ini dilakukan dalam tiga siklus yang bertujuan untuk meningkatkan aktivitas siswa pada pembelajaran menirukan pembacaan pantun anak masing-masing siklus dilakukan dalam satu kali pertemuan (2x35 menit). Berikut ini disajikan hasil pelaksanaan tindakan setiap siklus.

\section{Hasil Pelaksanaan Tindakan Siklus 1 \\ Pembelajaran dilaksanakan oleh guru sebagai kolabolator. Hal ini dilakukan agar kelas tetap terjaga kealamiahannya. Harapannya proses}


belajar siswa tidak terganggu dan proses pembelajaran di kelas berlangsung optimal.

Berdasarkan hasil observasi yang telah dilakukan oleh teman sejawat bahwa perencanaan yang telah dilakukan oleh guru telah memenuhi persyaratan. Untuk mengajarkan mata pelajaran Bahasa Indonesia di kelas IV SD Negeri19 Kepahiang pada kompetensi dasar "Menirukan pembacaan pantun anak dengan lapal dan intonasi yang tepat", guru telah mempersiapkan beberapa hal diantaranya rencana perbaikan pembelajaran RPP I, alat peraga, LDS, lembar pengamatan keaktifan siswa, format penilaian hasil belajar siswa lembar soal terlengkap dengan kunci jawaban serta alat penilaian kemampuan guru yang mencantumkan 6 komponen yang harus diisi oleh teman sejawat. Berdasarkan hasil pengamatan yang telah dilakukan teman sejawat bahwa aktivitas siswa pada proses pembelajaran pada siklus I belum menampakkan peningkatan begitupun dengan nilai tes siswa yang belum mencapai target yang diinginkan. Berikut ini tabel hasil pengamatan aktivitas siswa pada Siklus I.

Tabel .1

Hasil Pengamatan Aktivitas Siswa pada Siklus I

\begin{tabular}{|c|c|c|c|}
\hline No. & $\begin{array}{c}\text { Jumlah } \\
\text { Siswa }\end{array}$ & $\begin{array}{c}\text { Siswa } \\
\text { Aktif }\end{array}$ & $\begin{array}{c}\text { Siswa } \\
\text { Tidak } \\
\text { Aktif }\end{array}$ \\
\hline 1. & 20 & 11 & 9 \\
\hline
\end{tabular}

Berdasarkan tabel di atas keaktifan siswa belum mencapai target yang diinginkan keaktifan siswa baru 55\% sedangkan menurut Depdiknas kelas dinyatakan aktif apabila siswa di kelas tersebut keaktifannya mencapai $85 \%$. Begitupun dengan ketuntasan belajar, pembelajaran dinyatakan tuntas apabila siswa yang memperoleh nilai $>6.5$ mencapai $85 \%$.

Tabel 2

Hasil Belajar siswa Siklus

\begin{tabular}{|c|c|c|c|c|c|}
\hline $\begin{array}{l}\mathrm{N} \\
\text { o. }\end{array}$ & $\begin{array}{c}\text { Jumlah } \\
\text { Siswa } \\
\text { yang } \\
\text { Tuntas }\end{array}$ & $\begin{array}{c}\text { Jumlah } \\
\text { Siswa } \\
\text { yang } \\
\text { BelumT } \\
\text { untas }\end{array}$ & $\begin{array}{c}\text { Nilai } \\
\text { rata- } \\
\text { rata }\end{array}$ & $\begin{array}{c}\text { Nilai } \\
\text { Ter } \\
\text { tinggi }\end{array}$ & $\begin{array}{c}\text { Nilai } \\
\text { Te } \\
\text { rendah }\end{array}$ \\
\hline 1 & 13 & 7 & 6,5 & 8 & 5 \\
\hline
\end{tabular}

Berdasarkan Tabel 2 di atas ketuntasan belajar pada siklus I baru mencapai $65 \%$. Berdasarkan skor tes dan hasil observasi tentang keaktifan siswa dan guru dalam proses pembelajaran pada siklus 1, guru menyadari bahwa kekurangan pada proses pembelajarannya mengakibatkan kurang berhasilnya pembelajaran.Guru kurang adil di dalam pembagian kelompok diskusi sehingga membuat diskusi tidak berjalan dengan semestinya. Masalah yang diberikan pada siswa kurang menantang, dan guru kurang mengarahkan jalannya diskusi.

Berdasarkan skor tes dan hasil observasi tentang keaktifan siswa dan guru dalam proses pembelajaran siklus 1,maka guru menyadari kekurangan pada proses pembelajarannya yang mengakibatkan kurang berhasilnya pembelajaran.Hal ini desebabkan oleh alasan berikut.

1. Guru kurang adil di dalam pembagian kelompok diskusi sehingga membuat diskusi tidak berjalan dengan semestinya.

2. Pertanyaan kurang menantang.

3. Diskusi kurang terarah.

Pada proses pembelajaran di siklus I, skor evaluasi belajar siswa baru mencapai 6,5 (65\%). Adapun keaktifan siswa baru mencapai $55 \%$ dapat dikatakan pembelajaran di siklus I belum berhasil karena belum mencapai target yang telah ditetapkan, hal ini dikarena guru belum bisa mengarahkan jalannya diskusi serta masalah yang didiskusikan kurang menantang siswa untuk berbuat aktif dalam proses pembelajaran.

\section{Hasil Pelaksanaan Tindakan Siklus II}

Berdasarkan kekurangan yang terjadi pada siklus I, maka guru akan melakukan perbaikan pada siklus II yaitu dengan cara sebagai berikut :

1. Di awal pembelajaran guru telah mempersiapkan dan membagi kelompok diskusi yang anggota tiap kelompok terdiri dari anak pintar, sedang dan kurang pandai. 
2. Permasalahan yang akan didiskusikan bisa memancing untuk siswa berbuat aktif yaitu melengkapi bagian tabel yang berisi jenisjenis usaha serta contohnya yang belum selesai.

3. Guru akan berkeliling dan melihat serta mengarahkan jalannya diskusi.

Dengan melakukan perbaikan seperti yang tersebut di atas maka keaktifan siswa mengalami peningkatan hal tersebut dapat dilihat pada table keaktifan siswa di bawah ini.

Tabel 3

Hasil pengamatan Aktivitas Siswa pada Siklus II

\begin{tabular}{|c|c|c|c|}
\hline No. & $\begin{array}{c}\text { Jumlah } \\
\text { Siswa }\end{array}$ & $\begin{array}{c}\text { Siswa } \\
\text { Aktif }\end{array}$ & $\begin{array}{c}\text { Siswa } \\
\text { Tidak } \\
\text { Aktif }\end{array}$ \\
\hline 1. & 20 & 15 & 5 \\
\hline
\end{tabular}

Keaktifan siswa pada siklus 2 lebih baik. Skor keaktifan siswa sudah mencapai $75 \%$ hasil belajar siswa juga mengalami peningkatan pada siklus 2,sebagaimana dapat dilihat pada tabel 4 berikut ini.

Tabel 4

Hasil Penilaian pada Siklus 2

\begin{tabular}{|c|c|c|c|c|c|}
\hline No. & $\begin{array}{c}\text { Jumlah } \\
\text { Siswa } \\
\text { yang } \\
\text { Tuntas }\end{array}$ & $\begin{array}{c}\text { Jumlah } \\
\text { Siswa } \\
\text { yang } \\
\text { Belum } \\
\text { Tuntas }\end{array}$ & $\begin{array}{c}\text { Nilai } \\
\text { Rata- } \\
\text { rata }\end{array}$ & $\begin{array}{c}\text { Nilai } \\
\text { Ter } \\
\text { tinggi }\end{array}$ & $\begin{array}{c}\text { Nilai } \\
\text { Te } \\
\text { rendah }\end{array}$ \\
\hline 1. & 15 & 5 & 7,1 & 10 & 5 \\
\hline
\end{tabular}

Berdasarkan tabel di atas dapat dilihat bahwa perolehan skor siswa mengalami peningkatan ketuntasan belajar siswa mencapai $75 \%$. Pada proses pembelajaran siklus II, skor tes siswa yang telah mengalami peningkatan dari 6,5 menjadi 7,1. Untuk mencapai ketuntasan maksimal guru masih perlu mengadakan perubahan. Berdasarkan hasil observasi yang telah dilakukan oleh teman sejawat di siklus berikutnya guru perlu melakukan hal berikut ini:

1. Melatih siswa untuk menarik kesimpulan.
2. Diakhir kegiatan diskusi guru kurang memberikan penguatan berupa pujian dan penghargaan.

Pada siklus 2 proses pembelajaran sudah mengalami peningkatan. Keaktifan siswa sudah berangsur membaik, tetapi menurut teman sejawat masih terdapat kekurangan dalam proses pembelajaran.

1. Guru kurang melatih siswa untuk membuat kesimpulan pada saat diskusi, kurang memberi penguatan pada akhir diskusi berupa pujian dan penghargaan.

2. Guru kurang memberikan penguatan maupun pujian pada siswa di akhir siklus.

3. Pada pembelajaran di siklus 2 keaktifan siswa sudah berangsur membaik. Hal ini berdampak pada skor siswa yang mengalami peningkatan dari skor ratarata $6,5(65 \%)$ menjadi $7,1(75 \%)$ hal ini kaena guru memperbaiki kekurangan pada siklus 1 .

Pada proses pembelajaran siklus 2 juga belum mencapai target yang telah ditentukan. Hal ini dikarenakan guru kurang melatih siswa untuk menarik kesimpulan. Pada saat diskusi,diketahui guru kurang memberi penguatan pada akhir diskusi berupa pujian dan penghargaan. Hal ini sesuai dengan teknik diskusi serta langkah-langkah metode diskusi dalam pembelajaran.

Pada pembelajaran di siklus 2 keaktifan siswa sudah berangsur membaik dan berdampak pada skor siswa yang mengalami peningkatan dari skor rata-rata 6,5 (65\%) menjadi 7,1 (75\%). Hal ini dikarenakan guru memperbaiki kekurangan pada siklus 1. Pada proses pembelajaran siklus 2 juga belum mencapai target yang telah ditentukan. Hal ini dikarenakan guru kurang melatih siswa dalam menarik kesimpulan. Pada saat diskusi, guru juga kurang memberi penguatan pada akhir diskusi berupa pujian dan penghargaan. Hal ini sesuai dengan teknik diskusi serta langkah-langkah diskusi dalam pembelajaran. 


\section{Hasil pelaksanaan Tindakan Siklus III}

Pada siklus 3 ini pembelajaran dititik beratkan pada perbaikan yang sudah dijelaskan pada siklus 2. Pada siklus 3 ini guru merasa bahwa proses pembelajaran memang perlu diteliti dan dilakukan perubahan sehingga tahap demi tahap guru harus menyadari apa kekurangan di dalam proses pembelajaran dan kekurangan itu harus diperbaiki.

Dengan mempelajari hasil observasi yang telah dilakukan teman sejawat pada siklus 3 ini guru melakukan tindakan perbaikan yang seperti tertulis pada hasil refleksi siklus 2 di atas. Upaya perbaikan yang dilakukan tidaklah siasia,terbukti bahwa skor siswa pada siklus 3 mengalami peningkatan yang maksimal. Demikian juga siswa sudah berani mengemukakan pendapat hal ini dapat dubuktikan dengan tabel keaktifan siswan berikut ini.

Berdasarkan nilai pada tabel di atas bahwa keaktifan siswa sudah mencapai $90 \%$. Hal ini menunjukkan bahwa keaktifan siswa sudah mencapai target yang telah ditetapkan Depdiknas (1996). Adapun berdasarkan skor pada tabel 6 di atas dapat diketahui bahwa hasil belajar siswa sudah mencapai ketuntasan yang maksimal. Ketuntasan belajar secara klasikal adalah 90\%.

Proses pembelajaran yang berlangsung pada siklus 3 sudah dinyatakan maksimal hal ini dikarenakan guru selalu mempelajari dan berusaha memperbaiki kekurangan pada siklus 1 dan 2.

Pada siklus 3 proses pembelajaran sudah mencapai target yang diinginkan. Hal ini karena guru selalu memperbaiki kekurangan pada siklus 1 dan 2. Pada siklus 3 ada 2 siswa yang belum tuntas hal ini dikarenakan siswa tersebut memiliki keterbatasan dalam belajar,sering tinggal kelas dan kurang mendapat perhatian dari orang tua.

\section{SIMPULAN}

Berdasarkan analisis terhadap data hasil penelitian tindakan kelas ini dapat disimpulkan bahwa penerapan metode diskusi pada pembelajaran tentang pantun di kelas IV SD
Negeri 19 Kepahiang dapat memperbaiki prestasi belajar siswa pada kegiatan akhir pembelajaran.

\section{SARAN}

Berdasarkan kesimpulan di atas penulis menyarankan agar pada saat menyampaikan materi pembelajaran tentang pantun sebaiknya guru menerapkan metode diskusi. Dengan demikian,aktivitas siswa pada proses belajar membaik dan prestasi belajar siswa pada kegiatan akhir pembelajaran meningkat.

\section{DAFTAR PUSTAKA}

Winataputra (2007), Strategi Belajar Mengajar. Jakarta: Universitas terbuka.

Mulyasa (2008), Menjadi Guru Profesional Menciptakan Pembelajaran kreatif dan menyengkan. Bandung: Remaja Rosdakarya.

Wardani, I. G. A. K.; Wihardit, K; Nasution, N. (2008). Penelitian Tindakan Kelas. Jakarta: Univervsitas Terbuka.

Prianto,Puji Lestari,2007. Pendidikan Anak di SD Jakarta: Uniersitas Terbuka. 